\title{
鉄骨梁貫通孔の梁端からの限界距離について
}

\section{ON THE ACCESS LIMIT OF WEB PERFORATION TO STEEL BEAM END}

\author{
加藤 勉*, 金子洋 文** \\ Ben KATO and Hirofumi KANEKO
}

\begin{abstract}
The basic condition of limit state design for beams is that beams show sufficient plastic deformation capacity by generating plastic hinges at the beam ends. Concerning beams with web perforation, this condition is also satisfied when opening located in a distance from the beam end is not dameged prematurely.

In this paper, design formulae for evaluating strength of opening part and limit distance of the opening from the beam end are proposed. And an experiment was performed for verifing the propriety of the design formulae and the plastic deformation capacity of the beams with web opnenings.
\end{abstract}

Keywords : perforated beam, $M-Q$ interaction formula, location of openings, plastic deformation capacity

有孔梁, M-Q相関式, 孔位置, 塑性変形能力

1.はじめに

ウェブに貫通孔のある H 形断面梁の耐力に関する曲げーせん断相 関関係に関する研究は数多く発表されている。実際の設計に於て は、これらの研究成果(1)を用いて、無孔部分と同等の耐力を有する よう孔周辺に補強を施し、一種の全強設計とするのが普通である。 梁の耐震設計（一般的には終局限界状態設計）の基本条件は、梁 端に塑性ヒンジが生じて、十分な塑性変形能力を発揮することであ る。有孔梁の場合、孔部分に早期の損傷が生じて、この条件を阻害 しないことが必要である。

骨組内の梁の曲げモーメント、せん断力は、材長に沿って変化す るので、梁の終局限界状態に於て、任意の孔位置に作用する曲げ モーメント、せん断力が、その孔部分のモーメント耐力、せん断耐 力より小さいことが確認されれば、上記の条件は満足される。従っ て、全強設計の必要はない。

本論文では、最初に有孔部分の曲げ酎力とせん断耐力の相関関係 に関する既往の研究成果を照查し、不十分な部分について補足す る。次に終局限界状態における梁の曲げモーメント：せん断力分布 を求め、任意の孔位㯰における曲げモーメント、せん断力が孔部分 の曲げモーメント耐力、せん断耐力より小さいという条件から、有 孔梁の孔位置や所要耐力に関する設計式を導く。最後に実験によっ て、この設計式の妥当性を検証する。

\section{2. 有孔梁の設定条件}

本論文で対象とする有孔梁の適用範囲を以下に示す。 (1)貫通孔は基本的には補強しないものとする。
(2)横座屈を拘束されている大梁は梁端で塑性ヒンジを形成し、十分な 塑性变形能力を発揮できる幅厚比を有するものを対象とする。梁端が 終局状態に達するまで、スパン中央部分の耐力は全塑性酎力以下であ り、全塑性耐力まで耐力が低下しない程度に大きい幅厚比も対象とす る。

(3)塑性化領域の梁端部に貫通孔を設ける場合にウェプ板厚 $\mathrm{tw}$ があまり 大きくなる場合には貫通孔を補強する。

(4)梁成に対して貫通孔は概わ中心に設ける。

(5)孔径 $2 \mathrm{R}$ ( $\mathrm{R}$ : 半径) はウェブ成h $(=\mathrm{H}-2 \mathrm{t} \mathrm{f})$ に対して $2 \mathrm{R}<0.6 \mathrm{~h}$ とす る(図 1 参照)。

(6)複数孔の時は孔のピッチを $\mathrm{p}>\mathrm{h}$ する（図 1参照）。 (7)有孔，無孔に拘わらず、梁端の耐力が降伏せん断耐力で決まらない ような梁とする。

\section{3. 貫通孔の限界位置について}

梁端が全塑性耐力に達した時に、有孔部の耐力がそこに作用する外 力と同等となる梁端からの限界位置を限界距離と定義する。ここで は、先ず有孔部の耐力式を評価する。次にこの耐力式を基に貫通孔の 限界距離を決定するための設計式を誘導する。

\section{1 有孔部の耐力式 \\ 有孔梁の曲げ耐力とせん断耐力の相関関係を以下に示す。}

\subsection{1 梁端部の全望性耐力}

梁端部（無欠損部）の全塑性状態における曲け耐力MEとせん断耐 


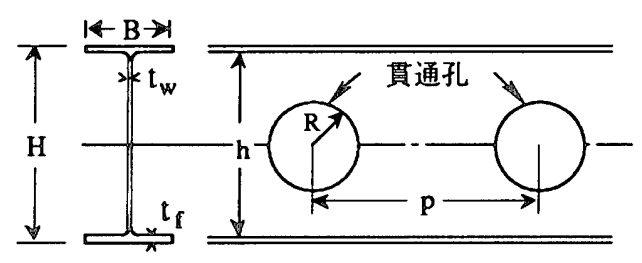

図1 梁端面，貫通孔寸法

力QEのM-Q相関関係を次式で近似する。（図 2参照）

$$
\begin{aligned}
\mathrm{ME} & =\left(M_{P}-M_{P f}\right)\left(1-\frac{Q_{E}}{Q_{y}}\right)+M_{P f} \\
& =M_{P}-\left(M_{P}-M_{P f}\right) \frac{Q_{E}}{Q_{y}}
\end{aligned}
$$

$\mathrm{QE}_{\mathrm{E}}<\mathrm{Q}_{\mathrm{y}}$

ここに、

$$
\begin{array}{ll}
\mathrm{M}_{\mathrm{P}}=\mathrm{M}_{\mathrm{Pf}}+\mathrm{M}_{\mathrm{Pw}_{\mathrm{w}}} & : \mathrm{H} \text { 形断面の全塑性モーメント } \\
\mathrm{M}_{\mathrm{Pf}}=\mathrm{B} \mathrm{t}_{\mathrm{f}}\left(\mathrm{h}+\mathrm{t}_{\mathrm{f}}\right) \sigma_{\mathrm{yf}} & : \text { フランジの全塑性モーメント } \\
\mathrm{M}_{\mathrm{Pw}}=\frac{1}{4} \mathrm{~h}^{2} \mathrm{t}_{\mathrm{w}} \sigma_{\mathrm{yw}} & : \text { ウェプの全塑性モーメント } \\
\mathrm{Qy}_{\mathrm{y}}=\frac{1}{\sqrt{3}} \mathrm{~h} \mathrm{t}_{\mathrm{w}} \sigma_{\mathrm{yw}} & : \text { ウェプの降伏せん断耐力 } \\
\sigma_{\mathrm{yf}} & : \text { フランシの降伏応力度 } \\
\sigma_{\mathrm{yw}} & : \text { ウェフの降伏応力度 }
\end{array}
$$

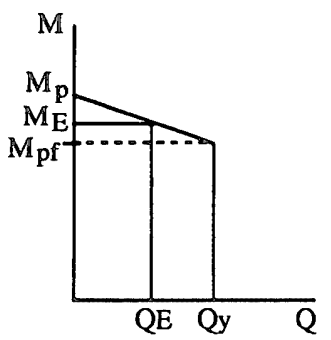

図 2 梁端部のM-Q相関関俰

\subsection{2 無補強有孔部の全塑性耐力}

ウェブ幅厚比が文献5)のFAランクあるいは文献6)の幅厚比区分P. I （十分な塑性変形能力を発揮できる幅厚比）の領域（幅厚比々と称す る）に貫通孔を設ける場合、全塑性状態における有孔部の曲げ耐力 $\mathrm{Mh}$ とせん断耐力 $\mathrm{Qh}$ のM-Q相関関係を求める。フィーレンディール効 果を考虑した有孔部のウェフの降伏せん断耐力Qphと $\mathrm{Q}=\mathrm{QPh}$ 時のフラ ンシの全塑性モーメントMPh が文献3)に与えられている。ここでは、 それを引用し、相関関係を次式で近似する。（図 3参照）

$$
M_{h}=M_{P h}-\left(M_{P h}-M_{P h f}\right) \frac{Q_{h}}{Q_{P h}}, \quad Q_{h}<Q_{P h}
$$

ここに、

$$
\begin{aligned}
& M_{\mathrm{Ph}}=B \mathrm{t}_{\mathrm{f}}\left(\mathrm{h}+\mathrm{t}_{\mathrm{f}}\right) \sigma_{\mathrm{yf}}+\frac{1}{4}\left(\mathrm{~h}^{2}-4 \mathrm{R}^{2}\right) \mathrm{t}_{\mathrm{w}} \sigma_{\mathrm{yw}} \\
& \quad: \mathrm{Q}=0 \text { の時の有孔部の全塑性モーメント } \\
& M_{\mathrm{Phf}}=\left(1-\frac{\mathrm{h} \mathrm{t}_{\mathrm{w}}}{2 \mathrm{~B} \mathrm{t}_{\mathrm{f}}}\right) \mathrm{M}_{\mathrm{Pf}} \\
& \quad: \mathrm{Q}=\mathrm{QPh} \text { 時の有孔部のフランジの全塑性モーメント } \\
& \mathrm{Q}_{\mathrm{Pf}}=\alpha(1-2 \overline{\mathrm{R}}) \mathrm{Q}_{\mathrm{y}} \quad: \text { 有孔部のウェプの降伏せん断耐力 } \\
& \overline{\mathrm{R}}=\mathrm{R} / \mathrm{h} \\
& \begin{array}{l}
\alpha=1-0.334\left(1-0.93 \overline{\mathrm{t}}_{\mathrm{f}}\right) \overline{\mathrm{R}}-0.064\left[\left(1-0.93 \overline{\mathrm{t}}_{\mathrm{f}}\right) \overline{\mathrm{R}}\right]^{2} \\
-2.336\left[\left(1-0.93 \overline{\mathrm{t}}_{\mathrm{f}}\right) \overline{\mathrm{R}}\right]^{3}
\end{array}
\end{aligned}
$$

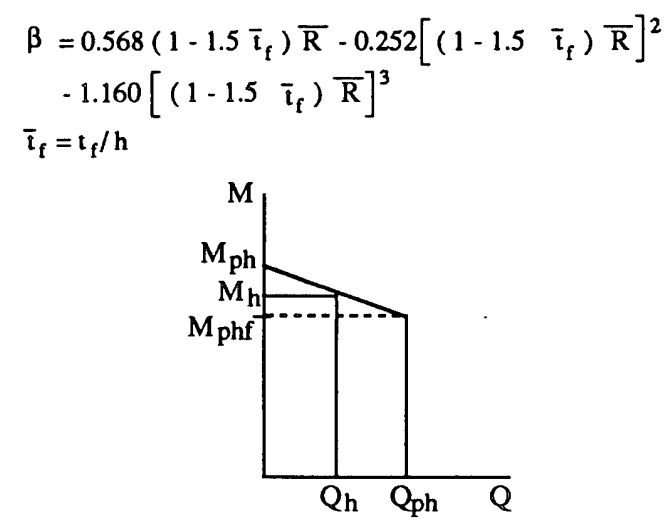

図 3 有孔部のM-Q相関関係

\subsection{3 無補強有孔部の弾性限耐力}

ウェブ幅厚比がFCランクあるいは幅厚比区分P-四（全塑性酎力ま で耐力が低下しない程度の大きさの幅厚比）の領域（幅厚比しと称す る）に貫通孔を設ける場合、有孔部の耐力を弾性限耐力とし、(2)式を 修正する。弾性限耐力時における有孔部の曲战耐力 $\mathrm{eMh}$ とせん断酎力 $\mathrm{eQh}$ のM-Q相関関係を次式で近似する9。（図 4 参照）

$$
{ }_{e} M_{h}=M_{\text {eh }}-\frac{e Q_{h}}{Q_{\text {eh }}}\left(M_{\text {eh }}-M_{\text {ehf }}\right), \quad e_{\text {e }} \leq Q_{\text {eh }}
$$

ここに、

$$
\begin{aligned}
& M_{e h}= 0.87 M_{P h} \\
&= 0.87\left[B t_{f}\left(h+t_{f}\right) \sigma_{y f}+\frac{1}{4}\left(h^{2}-4 R^{2}\right) t_{w} \sigma_{y w}\right] \\
&: Q=0 \text { 時の有孔部の弾性限モーメント } \\
& M_{\text {ehf }}=\left(1-\beta \frac{h t_{w}}{2 B t_{f}}\right) M_{e f}
\end{aligned}
$$

: $\mathrm{Q}=\mathrm{Q}$ eh 時の有孔部のフランジの弾性限モーメント

$$
\begin{aligned}
& \mathrm{M}_{\mathrm{ef}}=0.87 \mathrm{~B} \mathrm{t}_{\mathrm{f}}\left(\mathrm{h}+\mathrm{t}_{\mathrm{f}}\right) \sigma_{\mathrm{yf}} \quad: \text { フランジの弾性限モーメント } \\
& \mathrm{Q}_{\mathrm{eh}}=0.8 \mathrm{Q}_{\mathrm{Ph}}=0.8 \alpha(1-2 \overline{\mathrm{R}}) \mathrm{Q}_{\mathrm{y}} \\
& \quad: \text { 有孔部のウェプの弾性限せん断耐力 } \\
& \mathrm{Q}_{\mathrm{y}}=\frac{1}{\sqrt{3}} \mathrm{ht}{ }_{w} \sigma_{\mathrm{yw}}
\end{aligned}
$$

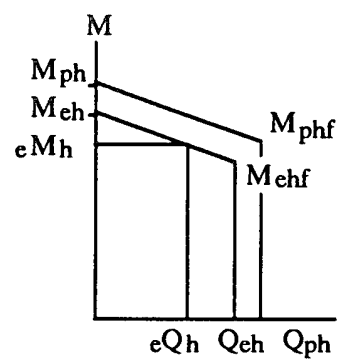

図 4 ウェフ十幅厚比しにおける有孔部のM-Q相関関係

\subsection{4補強有孔部の全塑性耐力}

貫通孔をリングプレートにより補強する場合の有孔部の耐力は、 ウェプ幅厚比Sの場合は全塑性耐力、ウェフ十幅厚比しの場合は弾性限耐 カとする。

補強有孔部のM-Q相関関係式は無補強有孔部の式(2)あるいは式(3) と同形とし、Mphr，Pph，Mehf，及びQehを下式によって修正する。リ ンクプレートが存在する場合のフィーレンディール効果を考虑した有 孔部のフランジの $\mathrm{Q}=\mathrm{QPh}$ 時の全塑性モーメントMPhrと降伏せん断耐力 


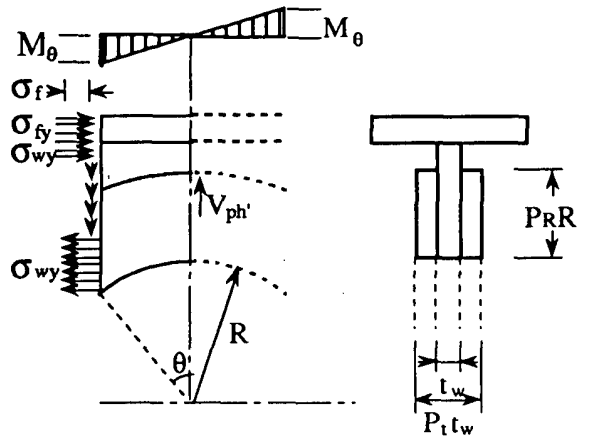

図 5 リンクフプレート補強有孔部

QPhは、文献1)に基づき、図 5 に示すように補強ブレートもせん断応 カ及びフランシの軸応力に釣り合う応力を分担すると仮定して求め る。

図中の of はフィーレンディール作用に釣り合うフランジ応力を示 し、 $\sigma_{\mathrm{fy}}$ - $\sigma_{\mathrm{f}}$ は全体曲げに対するフランジ応力となる。VPh'はフィーレ ンディール作用を考慮したせん断耐力である。また、P れリンクフプレートの板厚と板幅のウェブ厚と孔径に対する係数であ る。これより、幅厚比Sのウェフにおける有孔部のフランジのQ=QPh 時の全塑性モーメントMPhr と降伏せん断耐力QPhは、

$$
\begin{aligned}
& M_{\mathrm{Phf}}=\left(1-\beta^{\prime} \frac{\mathrm{htw}}{2 \mathrm{~B} \mathrm{t}_{\mathrm{f}}}\right) M_{\mathrm{Pf}} \\
& \mathrm{Q}_{\mathrm{Pf}}=\alpha^{\prime}(1-2 \overline{\mathrm{R}}) \mathrm{Q}_{\mathrm{y}}
\end{aligned}
$$

で表わされる。ここに、

$$
\alpha^{\prime}=A\left(P_{t}-1\right)+\alpha
$$$$
\mathrm{A}=12.98 \overline{\mathrm{R}}^{3}-2.788 \overline{\mathrm{R}}^{2}+1.754 \overline{\mathrm{R}}-0.033
$$

また、阳は孔径 $\overline{\mathrm{R}}$ と係数 $\mathrm{Pt}$ をパラメーターとして図 6 より求める。 また、幅厚比Lの場合には、

$$
\begin{aligned}
& M_{\text {ehf }}=\left(1-\beta^{\prime} \frac{h t_{w}}{2 B t_{f}}\right) M_{e f} \\
& Q_{e h}=0.8 \alpha^{\prime}(1-2 \bar{R}) Q_{y}
\end{aligned}
$$

を用いる。

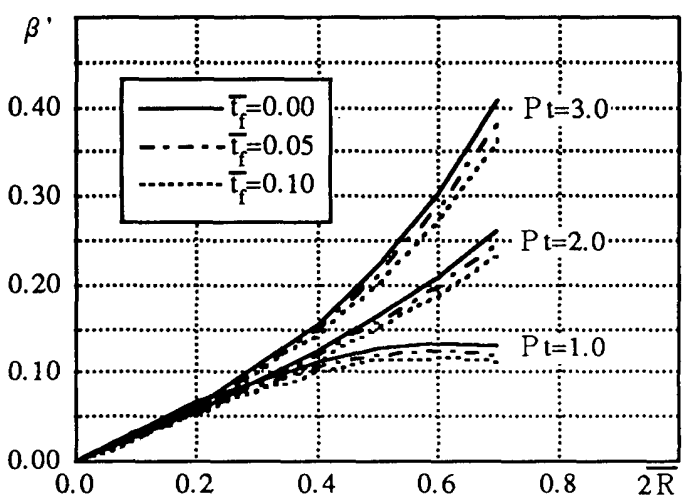

図 6 係数 $\beta^{\prime}$ と無次元化孔径 $\overline{\mathrm{R}}$ との関係

\section{2 限界距離算定式}

有孔部に作用する曲げモーメシトとせん断力が、有孔部の曲げ耐力 及びせん断耐力以下となるような貫通孔の梁端からの限界距離を求め る。

3.2 .1 梁に生じる㐫力分布

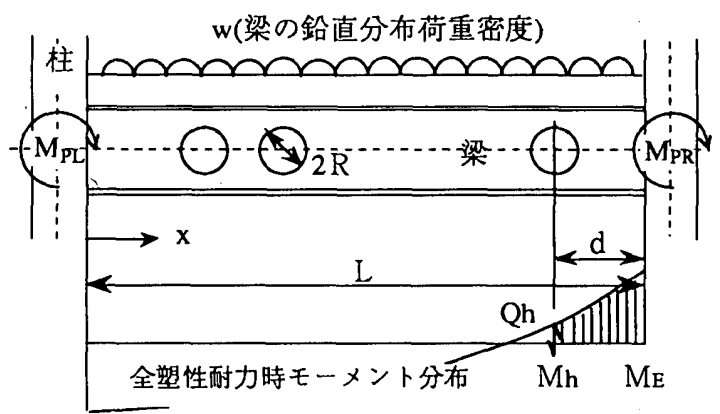

図 7 梁に作用する外力

（1）全塑性状熊の応力分布

図 7 に示すような水平荷重と等分布荷重wを受けるスパンLの梁が 材两端でせん断力を考虑した全塑性状態になっている時の応力分布 は、曲げモーメントとせん断力についてそれぞれ

$$
\begin{aligned}
& M_{x}=\left(1-\frac{x}{L}\right) M_{P L}-\frac{x}{L} M_{P R}+\frac{w}{2} x(L-x) \\
& Q x=\frac{\partial M_{x}}{\partial x}=-\frac{M_{P L}+M_{P R}}{L}+w\left(\frac{L}{2}-x\right)
\end{aligned}
$$

と表わせる。ここに、MPLとMPRはそれぞれ左端と右端の全塑性状態 における曲げモーメントである。

ここで、スパン中間に最大モーメントが生じないことを前提とす る。最大モーメント点では $\frac{\partial M x}{\partial x}=Q x=0$ であり、 $Q x=0$ となる点がス パン領域内に無い条件 $(x \leq 0)$ から

$$
\frac{w L^{2}}{2} \cdot\left(M_{P L}+M_{P R}\right) \leq 0
$$

を適用条件とする。

なお、(6)式を満たす時は(5)式のQxはスパン内で符号が変わらず負 值をとるが、せん断力は絶対値を用いるので(5)式も絶対値（正号）を とり

$$
\mathrm{Qx}_{\mathrm{x}}=\frac{\mathrm{M}_{\mathrm{PL}}+\mathrm{M}_{\mathrm{PR}}}{\mathrm{L}}-\mathrm{w}\left(\frac{\mathrm{L}}{2}-\mathrm{x}\right)
$$

で表わす。

（2）全塑性状態における材端応力

(5')式で $\mathrm{x}=0$ における $\mathrm{QL}$ と $\mathrm{x}=\mathrm{L} に お け る \mathrm{QR}$

$$
\begin{aligned}
& \mathrm{Q}_{\mathrm{L}}=\frac{\mathrm{M}_{\mathrm{PL}}+\mathrm{M}_{\mathrm{PR}}}{\mathrm{L}}-\frac{w \mathrm{~L}}{2} \\
& \mathrm{Q}_{\mathrm{R}}=\frac{\mathrm{M}_{\mathrm{PL}}+\mathrm{M}_{\mathrm{PR}}}{\mathrm{L}}+\frac{w \mathrm{~L}}{2}
\end{aligned}
$$

となる。梁端の全塑性状熊における曲げモーメントMPLとMPRは、(1) 式のQEにQLとQRを代入するとMPLとMPRの連立一次方程式となり、 それを解いて

$$
\begin{aligned}
& M_{P L}=\frac{2}{2+\sqrt{3}(h / L)} M_{P}+\frac{\sqrt{3}}{8} \text { whL } \\
& M_{P R}=\frac{2}{2+\sqrt{3}(h / L)} M_{P}-\frac{\sqrt{3}}{8} \text { whL }
\end{aligned}
$$$$
\cdots \cdot(8-a)
$$
を得る。ここで、(1)式のMEはMPLあるいはMPRに対応する。(7)式と (8)式より、梁端の全塑性状態におけるせん断力QLとQRは

$$
\begin{aligned}
& \mathrm{Q}_{L}=\frac{4 M_{P}}{[2+\sqrt{3}(h / L)] L}-\frac{w L}{2} \\
& \mathrm{Q}_{R}=\frac{4 \mathrm{M}_{\mathrm{P}}}{[2+\sqrt{3}(\mathrm{~h} / \mathrm{L})] \mathrm{L}}+\frac{w \mathrm{~L}}{2} \\
& \text {. . . (9-a) } \\
& \text {... (9-b) }
\end{aligned}
$$
となる。 


\section{（3）梁端から距離dの位置に作用する力}

$\mathrm{d}$ 位置の作用せん断力dQLとdQRは、(5')式で $\mathrm{x}=\mathrm{d}, \mathrm{L}-\mathrm{d}$ と置き、また (8)式のMPL，MPRを用いて

$$
\begin{aligned}
& d Q_{L}=\frac{4 M_{P}}{[2+\sqrt{3}(h / L)] L}-w\left(\frac{L}{2}-d\right) \\
& d Q_{R}=\frac{4 M_{P}}{[2+\sqrt{3}(h / L)] L}+w\left(\frac{L}{2}-d\right)
\end{aligned}
$$$$
\cdots(10-a)
$$

と妄わせる。d位置の作用曲げモーメントdMPLとdMPRは、(4)式で $\mathrm{x}=\mathrm{d} ， \mathrm{~L}-\mathrm{d}$ と置き、(8)式のMPL，MPRを用いて（MPRも絶対值をとる）

$$
\begin{aligned}
& { }_{d} M_{L}=\left[\frac{2-4(d / L)}{2+\sqrt{3}(h / L)}\right] M_{P}+\frac{w}{2}\left[\frac{\sqrt{3}}{4} h L+d(L-d)\right] \cdots(11-a) \\
& { }_{d} M_{R}=\left[\frac{2-4(d / L)}{2+\sqrt{3}(h / L)}\right] M_{P}-\frac{w}{2}\left[\frac{\sqrt{3}}{4} h L+d(L-d)\right] \cdots(11-b)
\end{aligned}
$$

と表わせる。

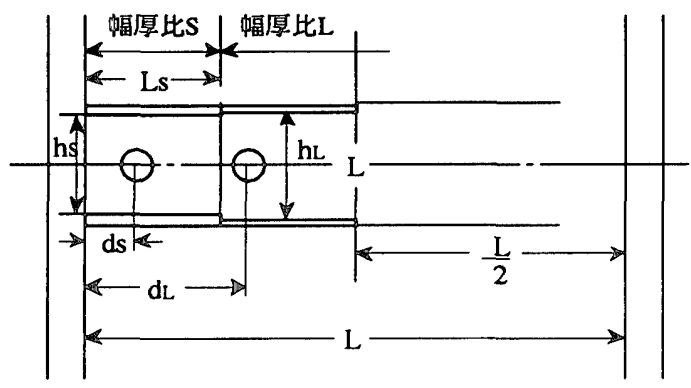

図 8 有孔梁の孔位置

\subsection{2 限界距離（図 8 参照）}

(1) 幅厚比Sのウェフ

梁端から位置dsに第 1 孔がある場合、(2)式の有孔部の曲外酎力Mh が(11)式の作用モーメントdMLとdMRに等しくなる時の有孔部のせん 断耐力Qh

$$
\begin{aligned}
\mathrm{Q}_{\mathrm{h}} & =\frac{\mathrm{Q}_{\mathrm{Ph}}}{\mathrm{M}_{\mathrm{Ph}}-\mathrm{M}_{\mathrm{Phf}}}\left\{\mathrm{M}_{\mathrm{Ph}}-\left[\frac{2-4(\mathrm{ds} / \mathrm{L})}{2+\sqrt{3}(\mathrm{~h} / \mathrm{L})}\right] \mathrm{M}_{\mathrm{P}}\right. \\
& \left.\mp \frac{\mathrm{w}}{2}\left[\frac{\sqrt{3}}{4} \mathrm{hL}+\mathrm{ds}(\mathrm{L}-\mathrm{ds})\right]\right\}
\end{aligned}
$$

となる。このQhが(10)式の作用せん断力dQL，dQRより大きいことが条 件となり、限界距離 $\mathrm{d}$ 学求める次式を得る。

$$
\begin{aligned}
& \frac{\mathrm{Q}_{\mathrm{Ph}}}{\mathrm{M}_{\mathrm{Ph}}-\mathrm{M}_{\mathrm{Phf}}}\left\{\mathrm{M}_{\mathrm{Ph}}-\left[\frac{2-4\left(\mathrm{~d}_{s} / \mathrm{L}\right)}{2+\sqrt{3}(\mathrm{~h} / \mathrm{L})}\right] \mathrm{M}_{\mathrm{p}}\right. \\
& \left.\mp \frac{w}{2}\left[\frac{\sqrt{3}}{4} h L+d s(L-d s)\right]\right\} \\
& >\frac{4 \mathrm{M}_{\mathrm{p}}}{[2+\sqrt{3}(\mathrm{~h} / \mathrm{L})] \mathrm{L}}+\mathrm{w}\left(\frac{\mathrm{L}}{2}-\mathrm{ds}\right)
\end{aligned}
$$

ただ、有孔部のウェフのせん断耐力Qhが有孔部のウェプの降伏せん 断耐力QPhより小さいことを確認しておく。ここで、Qhの值として (10)式を用い、(2)式で与えられるQPhから

$$
\begin{aligned}
& \frac{4 \mathrm{M}_{\mathrm{P}}}{[2+\sqrt{3}(\mathrm{~h} / \mathrm{L})] \mathrm{L}} \mp w\left(\frac{\mathrm{L}}{2}-\mathrm{ds}_{\mathrm{s}}\right) \\
& \quad \leq \alpha(1-2 \overline{\mathrm{R}}) \mathrm{Q}_{\mathrm{y}}=\frac{\alpha}{\sqrt{3}}(1-2 \overline{\mathrm{R}}) \mathrm{ht}_{\mathrm{w}} \sigma_{\mathrm{yw}}
\end{aligned}
$$

となる。

(2)幅厚比しのウェフ

梁端から位置dLに第 1 孔がある場合、(3)式の有孔部分の弾性限曲げ
耐力Mehが(11)式の作用モーメント $\mathrm{dML}$ と $\mathrm{d} \mathrm{MR}$ に等しくなる時の有孔部 のウェフのせん断耐力。Qhは

$$
\begin{aligned}
{ }_{e} \mathrm{Q}_{\mathrm{h}} & =\frac{\mathrm{Q}_{\mathrm{eh}}}{\mathrm{M}_{\mathrm{eh}}-\mathrm{M}_{\mathrm{ehf}}}\left\{\mathrm{M}_{\mathrm{eh}} \cdot\left[\frac{2-4\left(\mathrm{~d}_{\mathrm{L}} / \mathrm{L}\right)}{2+\sqrt{3}(\mathrm{~h} / \mathrm{L})}\right] \mathrm{M}_{\mathrm{P}}\right. \\
& \left.\mp \frac{\mathrm{w}}{2}\left[\frac{\sqrt{3}}{4} \mathrm{hL}+\mathrm{d}_{\mathrm{L}}\left(\mathrm{L}-\mathrm{d}_{\mathrm{L}}\right)\right]\right\}
\end{aligned}
$$

となる。この。Qhが(10)式の作用せん断力 $\mathrm{dQL}, \mathrm{dQR}$ 与限界距離 $\mathrm{dL}$ 求める次式を得る。

$$
\begin{gathered}
\frac{Q_{e h}}{M_{e h}-M_{e h f}}\left\{M_{e h}-\left[\frac{2-4\left(d_{L} / L\right)}{2+\sqrt{3}(h / L)}\right] M_{P}\right. \\
\left.\mp \frac{w}{2}\left[\frac{\sqrt{3}}{4} h L+d_{L}\left(L-d_{L}\right)\right]\right\} \\
>\frac{4 M_{P}}{[2+\sqrt{3}(h / L)] L} \mp w\left(\frac{L}{2}-d_{L}\right)
\end{gathered}
$$

ただし、有孔部のウェブのせん断耐力。Qhが有孔部のウェプの弾性限 せん断耐力Qehより小さいことを確認しておく。これは(14)式と同じ形 であるが、dsをdLに置き換え、 $\alpha$ 前に0.8の係数を掛ける。

\section{4.実験による検証}

3 節で示した貫通孔が幅厚比FAランク，幅厚比区分P P I あるいは FCランク，幅厚比区分 $\mathrm{P}$ 一四のウェブ設けられる場合、また、これ ら貫通孔がリングプレートで補強された場合の有孔部の耐力に関する 理論式の妥当性を実験的に検証する。さらに、実験により有孔梁の塑 性恋形能力を把握する。

\section{1 実験概要}

ここでは、限界距離と孔位置の関係を明確にするために鉛直荷重 $\mathrm{w}=0$ とし、水平荷重による逆対称曲げモーメントとせん断力が作用す る荷重状態を扱う。

有孔部の酎力に関する理論式を検証するために、有孔部の降伏が先 行するように孔位置を設定する。これは、(13)式ないし(16)式から決 定される限界距離dよりも梁端から孔位置までの距離LHを短くすれば よい。ただし、梁全体としてせん断降伏が先行しないようにウェフの 降伏せん断耐力Qy が(5')式の作用せん断力Qx以上であることを確認す る。この限界距離dは、梁端と有孔部が同時に曲げとせん断を考虑し た全塑性耐力（あるいはウェブ幅厚比がFCランクの有孔部は弾性限 耐力）に達する時の孔位置である。そのため、孔位置が限界距離から 離れるに従い有孔梁は無孔梁の性状に近つ゚く。よって、貫通孔が LH=dに位置する有孔梁に対して、終局状㦔における塑性变形能力を 把握する。

試験体の諸元を表 1 に示す7 10\%。試験体の断面寸法を決定する上 で、フランジ幅厚比は文献5)のFAランクの制限值より小さく、また、 ウェブ幅厚比はFAランクあるいはFCランク（試験体NSとOWCシ リーズ）の制限值に設定した。これは、フランジの局部座屈による早 期崩壊の防止と、ウェフに対しては各制限值内で耐力, 塑性变形能力 等の最小值を得るためである。なお、幅厚比は表 2 の材料の機械的性 質に示す引張試験より求めた実降伏応力度を基に公称值に換算した。 貫通孔の開口率はウェフ成の50６0\%とした。有孔部と梁端の各せん 断耐力を比較してその最小值が有孔梁の降伏先行形となる。例之ば Qphが最小の場合には有孔部せん断降伏先行形、Qhが最小の場合には 
表 1 試験体の諸元

\begin{tabular}{|c|c|c|c|c|c|c|c|c|}
\hline \multirow{2}{*}{ 試䀫体名 } & \multirow[b]{2}{*}{ 断面寸法 } & \multirow{2}{*}{$\begin{array}{l}\text { 長さL } \\
\text { (nII) }\end{array}$} & \multirow{2}{*}{ 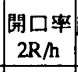 } & \multirow{2}{*}{$\begin{array}{l}\text { 限界界距酰 } \\
\mathrm{d}(\mathrm{cm})\end{array}$} & \multirow{2}{*}{\begin{tabular}{|l} 
flu位置 \\
$\mathrm{L}_{\mathrm{H}}(\mathrm{cm})$
\end{tabular}} & \multicolumn{2}{|c|}{ 有孔部 } & \multirow{2}{*}{$\begin{array}{l}\text { 梁端 } \\
\text { Qps(t) }\end{array}$} \\
\hline & & & & & & $\mathrm{Qph}(\mathrm{t})$ & $\mathrm{Qh}(\mathrm{t})$ & \\
\hline \begin{tabular}{l|l} 
OW 1-3.5 \\
FW-3.5 \\
WW \\
OW1-5.0 \\
FW-5.0
\end{tabular} & $\begin{array}{l}\text { BH- } 325 \times 125 \\
\times 6 \times 12 \\
\left(\frac{h}{t_{v}} \sqrt{\frac{\sigma_{y}}{F}}=58.5\right)\end{array}$ & 1,160 & $\begin{array}{l}0.54 \\
- \\
0.54 \\
-\end{array}$ & $\begin{array}{c}26.6 \\
- \\
29.2 \\
-\end{array}$ & $\frac{24.4}{24.4}$ & $\begin{array}{l}13.58 \\
- \\
13.58 \\
-\end{array}$ & $\begin{array}{c}15.87 \\
- \\
11.45 \\
-\end{array}$ & $\begin{array}{c}16.12 \\
- \\
11.79 \\
-\end{array}$ \\
\hline OWA & $\begin{array}{l}\text { BH-300 } \times 125 \\
(49.3) \times 6 \times 12\end{array}$ & 2,000 & 0.60 & 35.7 & 35.7. & 13.13 & 9.75 & 9.75 \\
\hline \begin{tabular}{l|l}
$\mathrm{N}$ & NSOW-R \\
$\mathrm{S}$ & NSOW \\
$\mathrm{O}$ & NSOW+R \\
W & NSFW \\
\end{tabular} & $\begin{array}{l}\text { BH-327 } \times 126 \\
\times 6 \times 12 \\
(60.0)\end{array}$ & 1,160 & $\begin{array}{l}0.50 \\
0.50 \\
0.50 \\
-\end{array}$ & $\begin{array}{l}23.2 \\
23.2 \\
23.2 \\
-\end{array}$ & $\begin{array}{c}15.6 \\
23.2 \\
30.8 \\
-\end{array}$ & $\mid \begin{array}{c}15.17 \\
15.17 \\
15.17 \\
- \\
\end{array}$ & $\begin{array}{c}16.56 \\
16.56 \\
16.56 \\
- \\
\end{array}$ & $\begin{array}{l}16.56 \\
16.56 \\
16.56 \\
- \\
\end{array}$ \\
\hline $\begin{array}{l}N \\
\text { S } \\
\text { NS-1 } \\
\text { NS-2 } \\
\text { NS-3 }\end{array}$ & $\begin{array}{l}\text { BH-375 } \times 125 \\
\times 69.2) \quad \times 6 \times 9\end{array}$ & $\begin{array}{l}1,500 \\
3,000 \\
1,000\end{array}$ & $\begin{array}{l}0.60 \\
0.60 \\
0.60\end{array}$ & $\begin{array}{c}66.7 \\
99.8 \\
- \\
\end{array}$ & $\begin{array}{l}40.0 \\
40.0 \\
-\end{array}$ & \begin{tabular}{|l|}
$10.75 *$ \\
$10.75 *$ \\
$10.75 *$
\end{tabular} & $\begin{array}{r}10.75^{*} \\
5.48^{*} \\
0\end{array}$ & $\begin{array}{r}12.96^{*} \\
6.48^{*} \\
0\end{array}$ \\
\hline 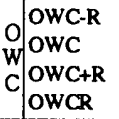 & $\begin{array}{c}\text { BH-365 } \times 125 \\
\times 669^{4} \times 12 \\
(60.9)\end{array}$ & $\left\{\begin{array}{c}2,920 \\
L 9= \\
760\end{array}\right.$ & $\begin{array}{l}0.535 \\
0.535 \\
0.535 \\
0.535\end{array}$ & $\begin{array}{r}106.4 \\
106.4 \\
106.4 \\
61.6\end{array}$ & $\begin{array}{r}97.2 \\
106.4 \\
115.5 \\
93.0\end{array}$ & $\begin{array}{l}15.55^{*} \\
15.55^{*} \\
15.55^{*} \\
33.10^{*}\end{array}$ & \begin{tabular}{r|}
$9.28 *$ \\
$9.66 *$ \\
$10.08 *$ \\
$10.94 *$
\end{tabular} & $\begin{array}{l}9.66 \\
9.66 \\
9.66 \\
9.66\end{array}$ \\
\hline \begin{tabular}{l|l} 
owR1 \\
W \\
R \\
R
\end{tabular} & $\begin{array}{l}\text { BH- } 325 \times 125 \\
\quad \times 6 \times 12 \\
(58.5)\end{array}$ & 1,160 & $\begin{array}{l}0.540 \\
0.540 \\
-\end{array}$ & $\begin{array}{l}18.5 \\
18.5 \\
-\end{array}$ & $\begin{array}{l}24.4 \\
15.0 \\
-\end{array}$ & $\begin{array}{l}22.46 \\
22.46 \\
-\end{array}$ & $\begin{array}{c}16.78 \\
15.50 \\
-\end{array}$ & $\begin{array}{c}15.86 \\
15.86 \\
-\end{array}$ \\
\hline
\end{tabular}

有孔部曲げせん断降伏先行形、Qpsが最小の場合には梁端部曲げせん 断降伏先行形である。表1に示す限界距離やせん断耐力もまた、実降 伏応力度を用いて算定した。

表 1において、OWシリーズの試験体OW1-3.5とOW1-5.0はせん断 スパン比をそれぞれ3.55と5.0とし、それぞれの孔位置は限界距離ds （ウェブ幅厚比S）より短く、同じ位置に設けている。これより、 OW1-3.5は有孔部でせん断降伏先行、OW1-5.0は有孔部で曲げせん断 降伏先行となる。試験体OWAは限界距離d $\mathrm{s}$ の位置に貫通孔を設けた ものであり、端部と有孔部が同時に全塑性耐力になる。NSOWシリー ズは、限界距離 $\mathrm{d}_{3}$ の位置に貫通孔を設けた試験体NSOW、限界距離よ りも孔径R分たけ限界距離より短い位置に貫通孔を設けた試験体 NSOW-R、限界距離よりも孔径R分だけ限界距離より長い位置に貫通 孔を設けた試験体NSOW+Rを設定した。たたし、全て有孔部でせん 断降伏先行するものである。NSシリーズは幅厚比しのウェブに貫通孔 を設けたものであり、孔位置は限界距離dしより短い。弾性限耐力の相 関関係において試験体NS-1は有孔部がせん断降伏と曲げ降伏を同時に 生しるもの、試験体NS-2は有孔部が曲げせん断降伏先行するもの、試 験体NS-3は有孔部が曲げ降伏先行するものである。OWCシリーズ は、梁端部のウェブ幅厚比S、中央部のウェブ幅厚比しの有孔梁であ る。試験体OWCは限界距離dLに貫通孔を設けたもの、試験体OWC \pm $\mathrm{R}$ は限界距離 $\mathrm{d} L$ の土Rの位置に貫通孔を設けたものである。なお、 OWCR試験体は図 9 に示す要領でウェブ両側の貫通孔を補強したもの であり、孔位置は限界距離dLよりも長い。OWRシリーズは幅厚比 $S$ の ウェブに設けた貫通孔をウェフの片側のみ補強したものであり、試験 体OWR1は貫通孔を限界距離dsうも短い位置に、試験体OWR2は貫 通孔を限界距離dょりも辰い位置に設けたものである。なお、各シ リーズで試験体名にFWの付く試験体は無孔梁である。ここでは、補 強板厚はウェブと同厚、リング幅は孔径 $2 R$ の1/4とした。

試験体は、図 9 に示すように両端単純支持，中央载荷（試験体NS3 は 2 点载荷の純曲げ）とし、スパン中央部が梁端を想定する加力点 であり、片側スパンを加力治具としている。片側1/3スパン毎に横補 剛材を設置した。

表 2 に材料の機械的性質、表 3 に各種算定耐力を示す。それぞれの
記号は 3 節で定義したものに対応する。なお、反pは梁端全塑性モーメ ント $\mathrm{M}_{\mathrm{p}}$ 時の加力点位置における弾性变位である。

\section{2 理論式の妥当性}

\subsection{1 荷重一变形関係}

各試験体の荷重一変位関係を図10に示す。絓軸はスパン中央に加え

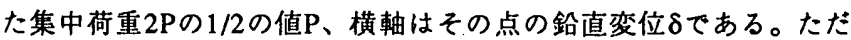
し、試験体NS-3には、単純支持点の両端から1/3の等スパン $1,000 \mathrm{~mm} の$ 位置を2点載荷して有孔部の中央スパンに等曲げモーメントを加え た。この場合の荷重Pと変位 $\delta$ は2点載荷点の平均值である。

有孔部がせん断降伏先行形の試験体OW1-3.5と NSOWシリーズは、 有孔部においてウェブがせん断座屈して張力場が形成された後、ウェ フ面内方向にフランジの垂直座屈"')が生じて耐力が低下した（写真1参 照）。その变形性状は、塑性化後に耐力上昇曲線の勾配が変形の進行

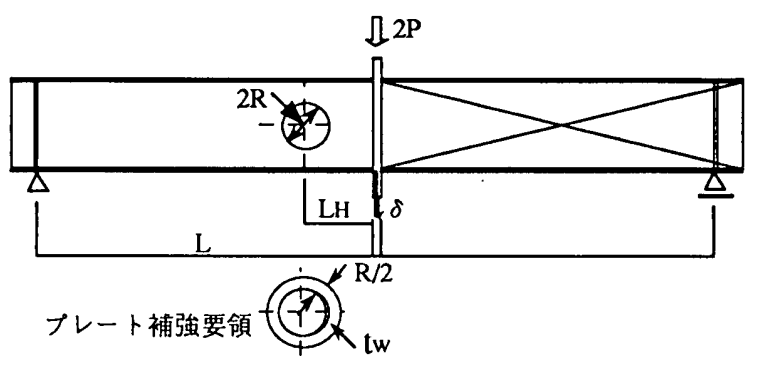

図 9 試験体形状

表 2 材料の機械的性質

\begin{tabular}{|c|c|c|c|c|c|}
\hline 試験体名 & 部位 & $\begin{array}{l}\text { 板厚 } \\
t(\mathrm{mn})\end{array}$ & $\begin{array}{c}\text { 降代応力度 } \\
\text { oy }\left(\mathrm{V} / \mathrm{cm}^{\circ}\right)\end{array}$ & $\begin{array}{l}\text { 引張蚛さ } \\
\sigma \mathrm{B}(\mathrm{v} / \mathrm{col})\end{array}$ & $\begin{array}{c}\text { 破断伸び } \\
(\%)\end{array}$ \\
\hline $\begin{array}{l}\text { OW1-3.5, FW-3.5 } \\
\text { OW1-5.0, FW-5.0 }\end{array}$ & $\begin{array}{l}\text { フランシ } \\
\text { ウェフ }\end{array}$ & $\begin{array}{r}11.55 \\
6.00\end{array}$ & $\begin{array}{l}3.62 \\
3.24\end{array}$ & $\begin{array}{l}5.44 \\
4.65\end{array}$ & $\begin{array}{l}27.6 \\
27.2\end{array}$ \\
\hline OWA & $\begin{array}{l}\text { フランシ } \\
\text { ウェフ }\end{array}$ & $\begin{array}{r}12.08 \\
6.15\end{array}$ & $\begin{array}{l}3.68 \\
3.98\end{array}$ & $\begin{array}{l}5.57 \\
5.73\end{array}$ & $\begin{array}{l}25.2 \\
23.3\end{array}$ \\
\hline $\begin{array}{l}\text { NSOW-R, NSOW } \\
\text { NSOW+R, NSFW }\end{array}$ & $\begin{array}{l}\text { フランシ } \\
\text { ウェフ }\end{array}$ & $\begin{array}{r}11.65 \\
5.94\end{array}$ & $\begin{array}{l}3.64 \\
3.30\end{array}$ & $\begin{array}{l}5.56 \\
4.68\end{array}$ & $\begin{array}{l}26.0 \\
27.2\end{array}$ \\
\hline NS-1, NS-2, NS-3 & $\begin{array}{l}\text { フランシ } \\
\text { ウェフ }\end{array}$ & $\begin{array}{l}8.95 \\
6.00\end{array}$ & $\begin{array}{l}3.73 \\
3.24\end{array}$ & $\begin{array}{l}5.61 \\
4.65\end{array}$ & $\begin{array}{l}24.9 \\
27.2\end{array}$ \\
\hline $\begin{array}{l}\text { OWC-R, OWC } \\
\text { OWC }+R \text {, OWCR }\end{array}$ & $\begin{array}{l}\text { フランシ } \\
\text { ウェフ }\end{array}$ & $\begin{array}{c}12.08 \\
6.15^{*}-9.07\end{array}$ & $\begin{array}{c}3.68 \\
3.98 \approx-3.80\end{array}$ & $\begin{array}{c}5.57 \\
5.73^{*}-5.60\end{array}$ & $\begin{array}{c}25.2 \\
23.3^{*} \sim 23.7\end{array}$ \\
\hline OWR-1, OWR-2, FW & $\begin{array}{l}\text { フランシ } \\
\text { ウェフ }\end{array}$ & $\begin{array}{l}11.60 \\
6.10^{*}\end{array}$ & $\begin{array}{l}3.48 \\
3.35^{*}\end{array}$ & $\begin{array}{l}5.47 \\
5.05^{*}\end{array}$ & $\begin{array}{l}26.3 \\
38.1^{*}\end{array}$ \\
\hline
\end{tabular}

*:リッ゙ブレートウェフ共通

表 3 各種算定耐力

\begin{tabular}{|c|c|c|c|c|c|c|c|c|c|c|c|c|}
\hline 試倹体名 & $\underset{(\mathrm{tcm})}{\mathrm{Mp}}$ & $\begin{array}{l}\text { Mpf } \\
(\mathrm{tcm})\end{array}$ & $\begin{array}{l}\text { Qy } \\
\text { (t) }\end{array}$ & $\begin{array}{l}\text { Mph } \\
\text { (tcm) }\end{array}$ & $\begin{array}{c}\text { Mphf } \\
\text { (tcm) }\end{array}$ & $\begin{array}{l}\text { Qph } \\
\text { (t) }\end{array}$ & $\begin{array}{c}\text { Mh } \\
(\mathrm{tcm})\end{array}$ & $\begin{array}{l}\text { Qh } \\
\text { (t) }\end{array}$ & $\begin{array}{l}\text { Meh } \\
(\mathrm{tcm})\end{array}$ & $\begin{array}{l}\text { Mehf } \\
(\mathrm{tcm})\end{array}$ & $\begin{array}{l}\text { Qeh } \\
\text { (t) }\end{array}$ & $\begin{array}{r}\delta \mathrm{p} \\
\text { (min) }\end{array}$ \\
\hline OW 1-3.5 & 2081 & 1638 & 33.88 & 1953 & 1526 & 13.58 & 1244 & 13.58 & & & & - \\
\hline FW-3.5 & " & " & $"$ & " & " & $"$ & - & - & & & & 6.56 \\
\hline OW $1-5.0$ & " & " & " & " & $"$ & " & 1593 & 11.45 & - & - & - & - \\
\hline FW-5.0 & " & $"$ & " & - & - & - & - & - & & & & 11.74 \\
\hline OWA & 2066 & 1600 & 38.98 & 1898 & 1498 & 13.13 & 1601 & 9.75 & - & - & - & 19.62 \\
\hline NSOW-R & 2139 & 1687 & 34.35 & 2026 & 1578 & 15.17 & 1523 & 15.17 & & & & - \\
\hline NSOW & " & " & $"$ & $"$ & $"$ & $"$ & 1408 & 15.17 & & & & - \\
\hline NSOW $+\mathrm{R}$ & " & " & " & " & " & " & 1292 & 15.17 & - & - & - & - \\
\hline NSFW & $"$ & " & $"$ & - & - & - & - & - & & & & 6.72 \\
\hline NS.1 & 2147 & 1528 & 40.08 & 1924 & 1359 & 13.43 & $1182 *$ & $10.75 *$ & 1647 & 1182 & 10.75 & - \\
\hline NS-2 & $"$ & $"$ & " & " & $"$ & $"$ & $1424 *$ & $5.48 *$ & " & $"$ & " & - \\
\hline NS-3 & $"$ & " & " & " & " & $"$ & $1674^{*}$ & $0 *$ & " & " & " & - \\
\hline OWC-R & 2962 & 1961 & 67.82 & 2468 & 1813 & 19.44 & $1807 *$ & $9.28^{*}$ & 2147 & 1577 & 15.55 & - \\
\hline owC & " & $"$ & $"$ & $"$ & " & " & $1793^{*}$ & $9.66^{*}$ & $"$ & $"$ & $"$ & - \\
\hline OWC+R & " & " & " & " & " & " & $1778^{*}$ & 10.08 & $"$ & " & " & - \\
\hline OWCR & " & " & " & 2978 & 1543 & 41.38 & 2178 & 10.94 & 2591 & 1342 & 33.10 & 33.26 \\
\hline OWR1 & 2047 & 1581 & 35.61 & 1912 & 1411 & 22.46 & 1537 & 16.78 & & & & - \\
\hline OWR2 & " & " & $"$ & $"$ & " & " & 1566 & 15.50 & - & - & - & - \\
\hline FW & " & " & " & - & - & - & - & - & & & & 6.51 \\
\hline
\end{tabular}



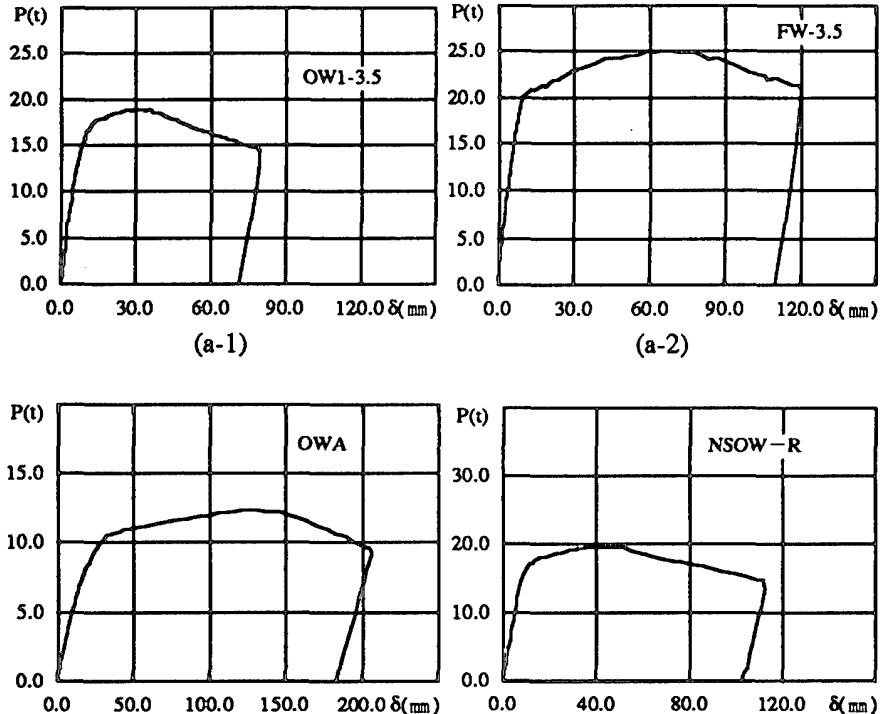

(c)

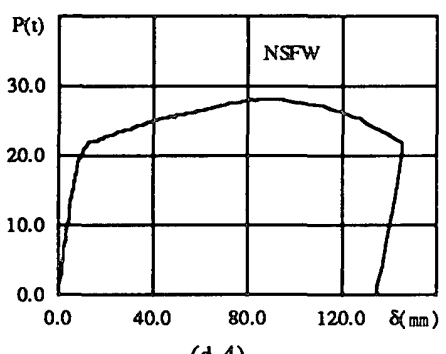

$(\mathrm{d}-4)$

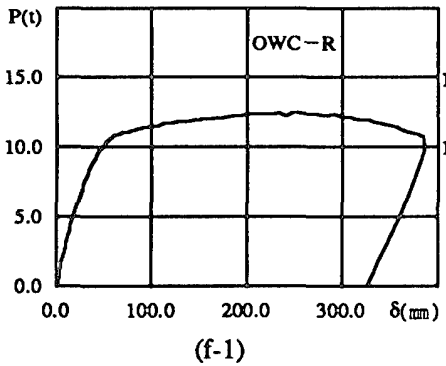

$(\mathrm{f}-1)$
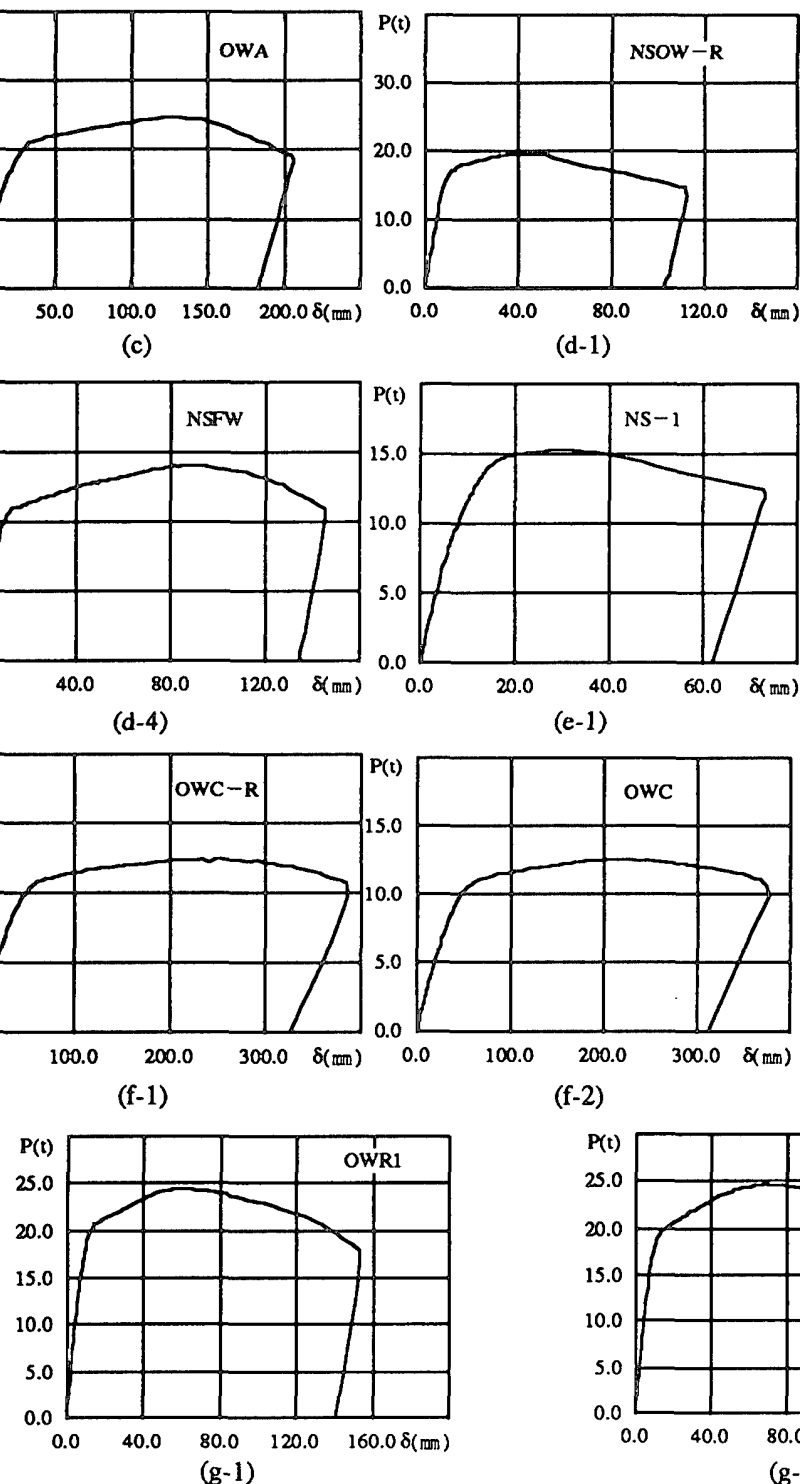

(d-1)

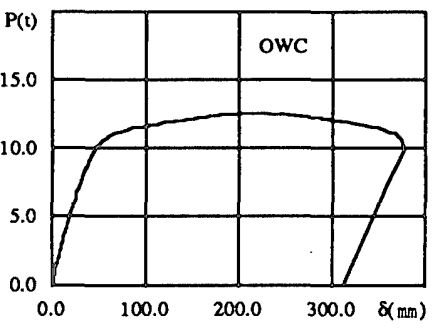

(f-2)
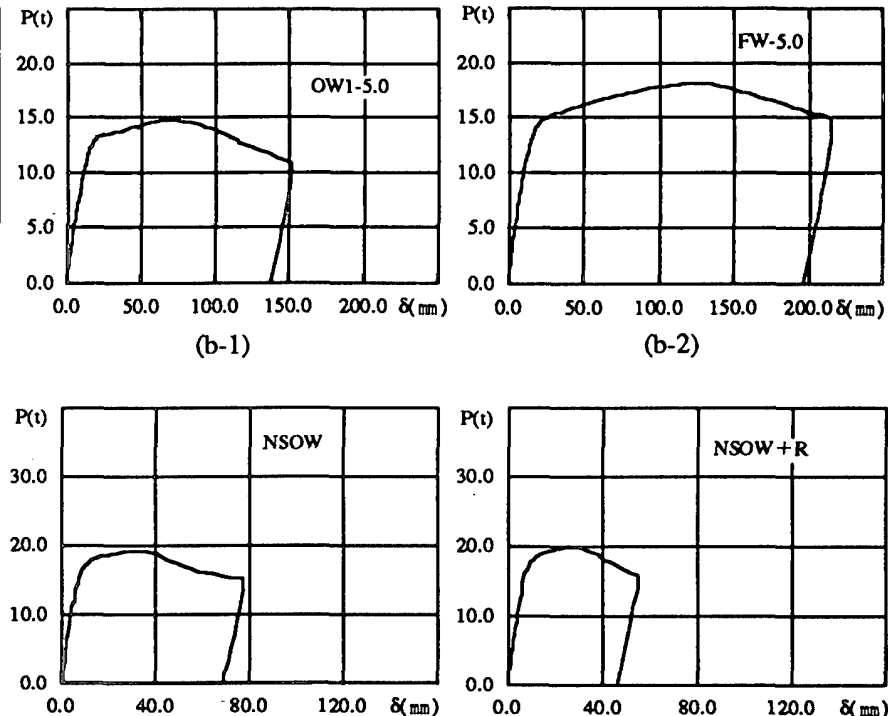

(d-2)

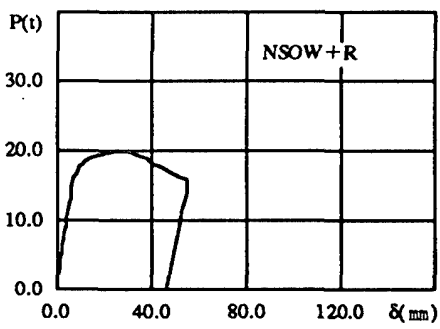

(d-3)

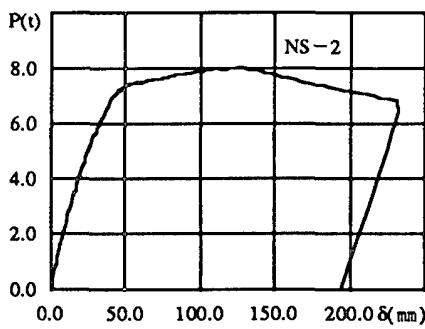

(e-2)

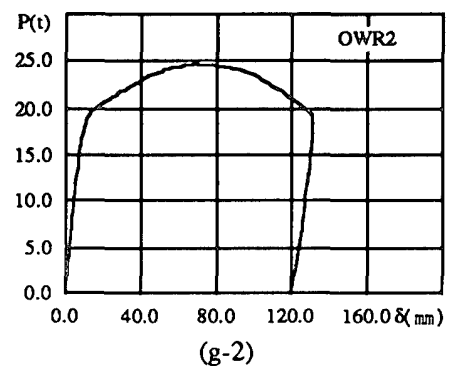

図10 荷重一変形関係

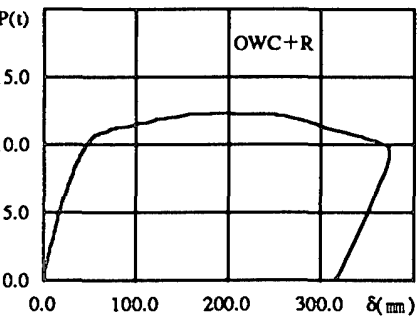

(f-3)
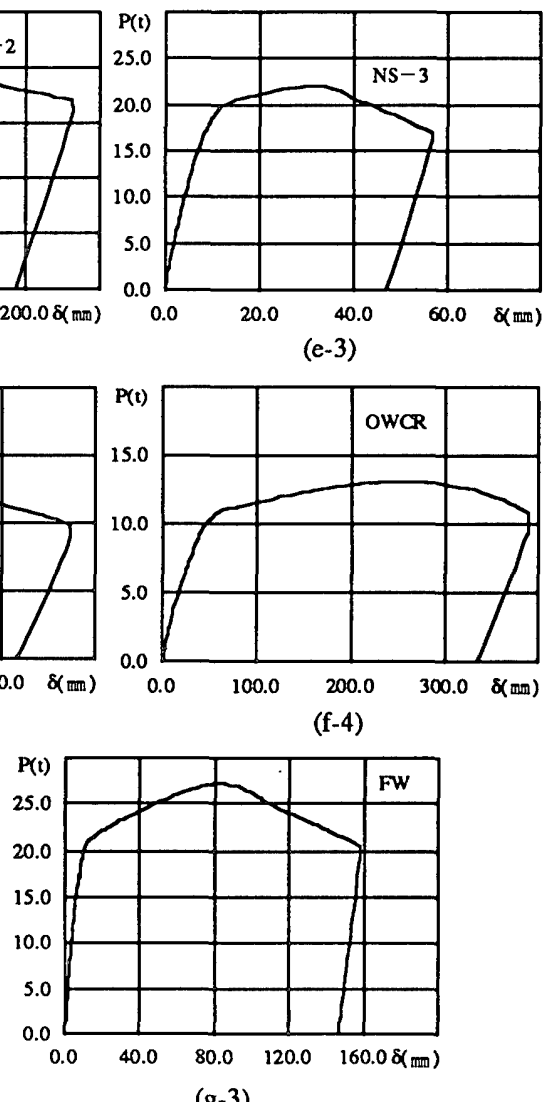

(g-3)

形を伴い酎力が低下した。有孔部が曲げせん断降伏先行形の試験体及 び曲げせん断崩壊形である無孔梁（FW）の変形性状は、塑性化後の 耐力上昇曲線の勾配が最大酎力までほは一定となる傾向がある。等曲 げモーメントを受ける試験体NS-3は、ウェフに曲げによる局部座屈が わずかに見られるが、フランジの局部座屈変形の增大により酎力が低 下した。各シリーズ毎の無孔梁に対する有孔梁の変形性状を比較する と、曲げせん断降伏先行形の試験体の方がせん断降伏先行形よりも塑 性変形性能が良い。なお、孔位置を変化させた試験体の中て、NSOW とOWRのシリースで孔位置が梁端に近い有孔梁の方が他の有孔梁よ りも塑性変形性状が良好であるが、これは梁端から貫通孔までの距離 
写其 1 試験体OW1-3.5

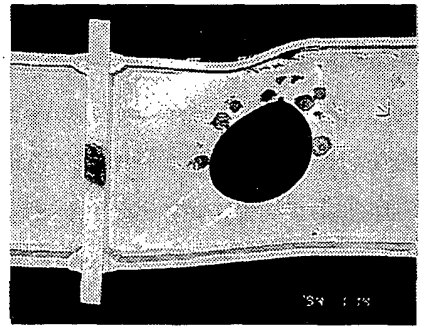

写真 2 試験体OWR 1
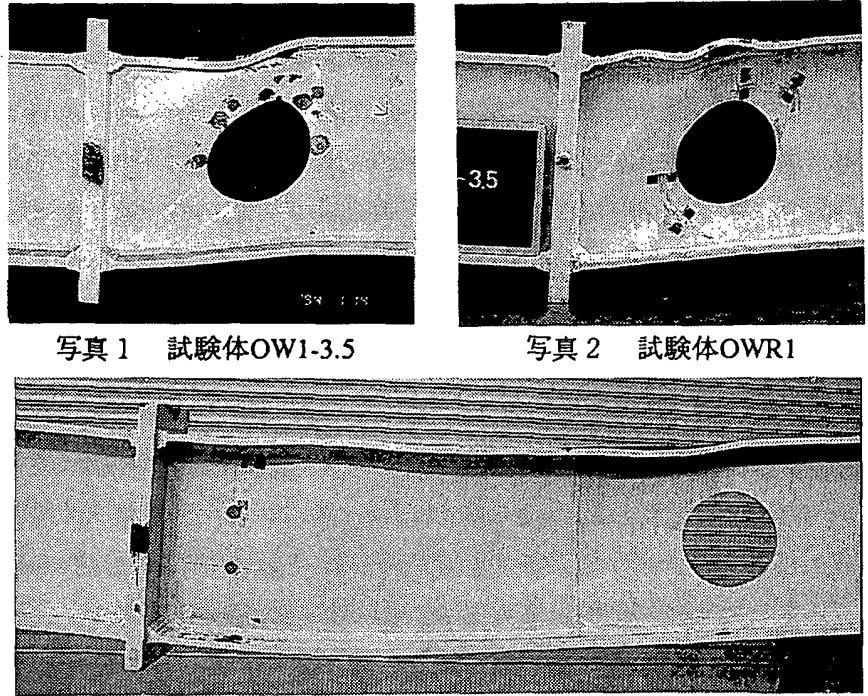

写真 3 試験体OWC

表 4 各種耐力の実験值

\begin{tabular}{|c|c|c|c|c|c|c|c|c|c|}
\hline \multirow[b]{2}{*}{ 試験体名 } & \multicolumn{3}{|c|}{ 全塑性酎力 } & \multicolumn{3}{|c|}{ 最大耐力 } & \multicolumn{3}{|c|}{ 弾性限酎力 } \\
\hline & $\begin{array}{l}\text { cMps } \\
\text { (tcm) }\end{array}$ & $\begin{array}{l}\text { eMphs } \\
\text { (tcm) }\end{array}$ & $\begin{array}{c}\text { eQps } \\
(t)\end{array}$ & $\begin{array}{c}\text { eMmaxs } \\
\text { (tcm) }\end{array}$ & $\begin{array}{c}\text { eMmaxh } \\
(\mathrm{tcC})\end{array}$ & $\begin{array}{c}e Q \max s \\
(t)\end{array}$ & $\begin{array}{l}\text { eMes } \\
(\mathrm{tcm})\end{array}$ & $\begin{array}{l}\text { eMehs } \\
\text { (tcm) }\end{array}$ & $\begin{array}{l}\text { eQes } \\
(\mathrm{l})\end{array}$ \\
\hline OW 1.3 .5 & - & 1521 & 16.60 & - & 1732 & 18.90 & & & \\
\hline FW-3.5 & 2320 & - & 20.00 & 2958 & - & 25.50 & - & - & - \\
\hline OW $1-5.0$ & - & 1795 & 12.90 & - & 2045 & 14.70 & & & \\
\hline FW-5.0 & 2354 & - & 14.40 & 2959 & - & 18.10 & & & \\
\hline OWA & 2096 & 1722 & 10.48 & 2470 & 2029 & 12.35 & - & - & - \\
\hline NSOW-R & - & 1736 & 17.29 & - & 1972 & 19.64 & & & \\
\hline NSOW & - & 1545 & 16.65 & - & 1772 & 19.10 & - & - & - \\
\hline NSOW $+R$ & - & 1500 & 17.60 & - & 1686 & 19.79 & & & \\
\hline NSFW & 2482 & - & 21.40 & 3270 & - & 28.19 & & & \\
\hline NS-1 & & 1575 & 14.32 & & 1681 & 15.28 & & 1370 & 12.45 \\
\hline NS-2 & - & 1862 & 7.16 & - & 2088 & 8.03 & - & 1620 & 6.23 \\
\hline NS-3 & & 1960 & 0 & & 2210 & 0 & & 1705 & 0 \\
\hline OWC-R & - & 2132 & 10.95 & - & 2418 & 12.42 & & 1855 & 9.53 \\
\hline owC & 3282 & 2086 & 11.24 & 3659 & 2326 & 12.53 & & 1815 & 9.78 \\
\hline OWC+R & 3282 & - & 11.24 & 3571 & - & 12.23 & & - & - \\
\hline OWCR & 3294 & - & 11.28 & 3828 & - & 13.11 & & - & - \\
\hline OWRI & 2332 & - & 20.10 & 2842 & - & 24.50 & & - & - \\
\hline OWR2 & - & 1909 & 18.90 & - & 2495 & 24.70 & - & - & - \\
\hline FW & 2390 & - & 20.60 & 3167 & - & 27.30 & & - & - \\
\hline
\end{tabular}

添字h：孔部位置

が梁成の $1 / 2$ よ短いので梁端プレート（加カプレート）により有孔 部のウェブ局部座屈変形が拘束されたためである。

表4は実験より得られた各種耐力である。全塑性耐力は、有孔部が 曲げせん断降伏先行形の試験体についてはgeneral yield法により、そ して有孔部がせん断降伏先行形の試験体については割線㴊性が初期剛 性の $2 / 3$ となった時の荷重一変形曲線の交点2)として求めた值である。 弾性限耐力を対象とする試験体については、有孔部の全塑性耐力の曲 げモーメント成分を(3)式に示す係数值0.87倍して弾性限の曲げモーメ ント及びせん断力を求めた。

\subsubsection{M-Q相関関係}

図11は有孔部の耐力に対する理論值と実験值の比較である。綎軸は 曲げモーメント、横軸はせん断力であり、それぞれ梁端の無孔部にお ける算定値の全塑性モーメント及び降伏せん断耐力で無次元化してい る。各試験体は(13)式あるいは(16)式で決定する限界距離かそれより 加力点側に近い位置に貫通孔がある有孔梁である。プロットは実験值 を示し、○印は全塑性耐力，○印は最大耐力，そしてロ印は弾性限耐
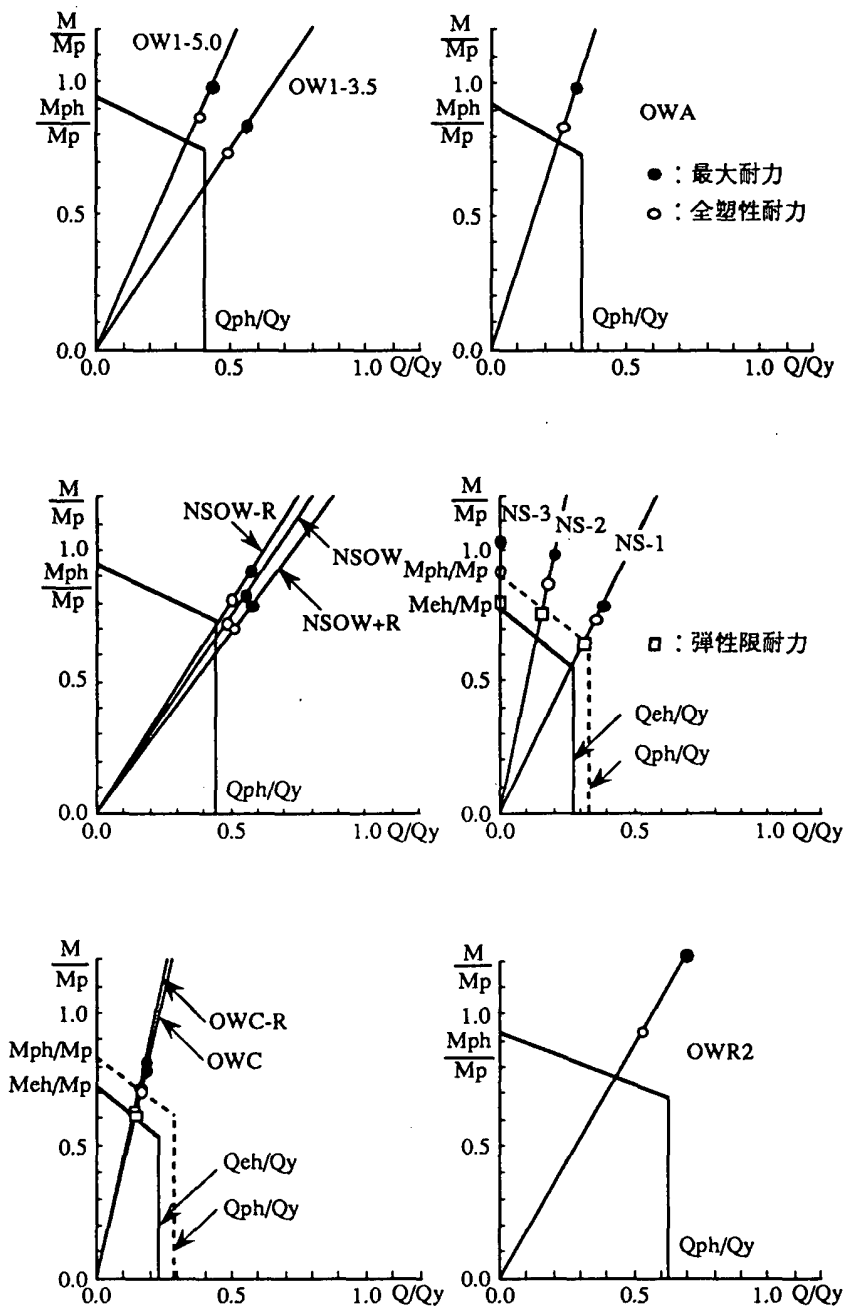

図11 M-Q相関関係

力である。全塑性耐力あるいは弾性限耐力に関しては、理論值と実験 值との対応は良好である。

\section{3 有孔梁の变形能力}

ここで対象とする有孔梁は、文献6)に示される構造区分S-I、また は文献5)に示されるFAランクを満足するものであり、十分な变形能力 を発揮することが要求される。

梁端に最も近い貫通孔の限界位置は、梁端が全塑性耐力に達した時 に有孔部の耐力がそこに作用する外力と同等以上となる位置と定義し ているが、梁の塑性変形能力は塑性域が梁端からスパン中央側にどの 程度広がり得るかによって決まる。このためには梁端部は全塑性耐力 より大きな耐力を発揮する必要があるが、同時に梁端に近い有孔部も その全塑性耐力（弾性限耐力）上りも大きい耐力をもつことが要求さ れる。ここでは、梁端部が全塑性酎力に達する時に、有孔部も全塑性 耐力（弾性限耐力）となる場合、有孔部が耐力上昇することにより、 有孔梁が耐力上昇して要求される塑性変形能力を満足するか調べる。

表 5 に孔位置と限界距離が同じ無補強の有孔梁試験体OWA, NSOW，及びOWC、そして孔位置がほほ限界距離にあるリングフ レート補強有孔梁試験体OWR 1 の最大耐力時の塑性変形能力Rmax （= $\delta \max / \delta \mathrm{p}-1 ）$ と最大耐力後の耐力が $90 \%$ まで低下した時の塑性変形 能力R0.9（= $\delta 0.9 / \delta \mathrm{p}-1 ）$ を示す。構造区分S-Iで要求される部材の塑性 
表 5 塑性変形能力

\begin{tabular}{|l|c|c|}
\hline & Rmax & R0.9 \\
\hline OWA & 5.62 & 7.91 \\
\hline NSOW & 4.06 & 6.52 \\
\hline OWC & 5.97 & 9.70 \\
\hline OWR1 & 8.97 & 17.19 \\
\hline
\end{tabular}

変形能力の下限は3.8 4.5である。有孔部がせん断降伏形する試験体 NSOWのRmax 44.06 であり、要求性能の下限值の範囲内であるが、 R0.91 6.52で十分な塑性变形能力である。その他の試験体は有孔部が 曲け゚せん断降伏形であるが、これらはRmaxが5.62以上、R0.9が7.91以上 あり、要求性能を十分满足している。試験体数は少ないが、有孔部が せん断降伏形よりも曲け゚せん断降伏形の方が変形能力に関しては優れ ていると考えられる。

ここに示した試験体は有孔部のせん断座屈とフランジの局部座屈に より最大耐力に至っている。また、ウェフの幅厚比は降伏応力度を公 称值の降伏応力度に換算して文献5)に示される各ランクの制限値とし た。従って、限界距離以上梁端から離れた位置に貫通孔を設ける有孔 梁の塑性変形能力は文献6)で与えられる要求性能を満足すると判断さ れる。

5.おわりに

十分な塑性変形能力を発揮できるウェブ幅厚比の小さい領域の無補 強の有孔部、全塑性酎力まで耐力が低下しない程度のウェブ幅厚比の 大きい領域の無補強の有孔部、そしてそれぞれのウェブ幅厚比の領域 で補強した有孔部の耐力式を設定し、孔位置の設計式を誘導した。こ れら有孔部の耐力式の妥当性と、本設計式に基づき貫通孔を設けた有 孔梁の耐力・塑性変形能力について実験的に検討した。以下に本論文 で得られた結諭を示す。

1) 限界距離算定式(13)及び(16)を用いて有孔部の降伏が梁端の降伏 に先行するように孔位置を設定した。実験值は全塑性耐力あるいは 弾性限耐力の理墖值を上回ることを示し、有孔部の耐力式を検証し た。

2）有孔梁の塑性変形能力が有孔部の性能に影響されると考えられる 限界距離に貫通孔を設けた有孔梁の塑性変形能力を㬰験的に検討し た。ウェブの幅厚比は降伏応力度を公称值の降伏応力度に換算して 文献5)に示される各ランクの制限值としたが、文献6)に示される要 求性能を渵足している。

3）有孔部がせん断降伏形の有孔梁は、孔位置に関わらず耐力が無孔 梁に達しない場合があること、塑性変形能力が曲げせん断降伏形に 比べて小さいことから、有孔部が曲げせん断降伏形となるように設 計することが望ましい。

\section{引用文献}

1)福知保長，土井康生，細川裕司：円形孔を有するはりの耐力と設計 法 1. 無補強の場合の耐力, 日本建築学会論文報告集, 第296号, 1980年10月, pp.27 36.

2)福知保長, 土井康生, 釜江克宏: 円形孔を有するはりの耐力と設計 法2.スリーブ管補強付の場合の耐力, 日本建榮学会論文報告集, 第301号，1981年3月，pp.43〜51.
3)土井康生, 福知保長 : 円形孔を有するはりの耐力と設計法 3. 実 用的耐力算定式の提案，日本建築学会論文報告集，第357号，1985 年11月, pp.44 51.

4)舟橋功男，小林昌一，山口育雄：鉄骨有孔梁に関する実験研究 そ の1一補強有孔板せん断試験一日本建築学会関東支部第38回学術研 究発表会, 1967年, pp.285 288.

5)日本建築センター：建築物の構造規定 一建築基準法施行令第3章 の解説と運用一，新洋社，1994年9月20日.

6)日本建築学会：鋼構造限界状態設計規準（案）・同解説，丸善株式 会社, 1990年2月 15 日.

7)広重隆明，加藤勉，木村衛，金子洋文，井ノ上一博，八木敦，関光 雄：幅厚比が小さい鉄骨有孔梁の耐力と塑性変形性能（その1 孔 位置の限界距離の定義），日本建築学会大会学術講演梗概集（東 海），1994年9月，pp.1117 1118.

8)八木毅，加藤勉，井ノ上一博，金子洋文，広重隆明，木村衛，関光 雄：幅厚比が小さい鉄骨有孔梁の耐力と塑性変形性能（その2 孔 位置の影響について），日本建築学会大会学術講演梗概集（東 海 ），1994年9月，pp.1119 1120.

9)松原由典，加藤勉，木村䚘，金子洋文，佐々木照夫，八木媇：スパ ン中央部の幅厚比が大きい鉄骨有孔梁の酎力と塑性変形能力, 日本 建淛学会大会学術講演梗概集（東海），1994年9月，pp.1121～ 1122.

10)広重隆明，加藤勉，金子洋文，宇佐美㧧，木村衛，伊藤武司：幅 厚比が小さい鉄骨有孔梁の耐力と塑性変形性能（その1 リングフ レート補強），日本建築学会大会学術講演梗概集（北海道），1995 年8月，pp.623 624.

11)土木学会: 座屈設計ガイドライン, 鋼構造シリーズ 2,1987 年 10 月. 